ing and the fifth carpometacarpal joint was visible but narrowed. The second, third, and fourth metacarpal bones were united to the adjacent radial carpal fusion.

This patient is probably the first to have received streptomycin for the treatment of skeletal tuberculosis (Hinshaw and Feldman 1945, 1946; Hinshaw, Feldman and Pfuetze 1946; Walker, Hinshaw and Barnwell 1949; Hinshaw, personal communication, 1993). At 47 years' follow-up she has only minimal functional disability.

No benefits in any form have been received or will be received from a commercial party related directly or indirectly to the subject of this article.

\section{REFERENCES}

Hinshaw HC, Feldman WH. Streptomycin in treatment of clinical tuberculosis: a preliminary report. Proc Staff Meet Mayo Clin 1945; 20:313-8.

Hinshaw HC, Feldman WH. Streptomycin in treatment of clinical and experimental tuberculosis. Ann NYAcad Sci 1946; 48:175-81.

Hinshaw HC, Feldman WH, Pfuetze KH. Treatment of tuberculosis with streptomycin: a summary of observations on 100 cases. JAMA 1946; 132:778-82.

Walker AM, Hinshaw HC, Barnwell JB. Streptomycin in the treatment of tuberculosis in man. In: Waksman SA, ed. Streptomycin: nature and practical applications. Baltimore: Williams \& Wilkins Company, 1949:291-319.

\title{
EARLY FAILURE OF METAL-BACKED PATELLAR ARTHROPLASTY
}

\section{NIELS LEVI, HAKON KOFOED}

Baech and Kofoed (1991) reported an $11 \%$ incidence of early failure of metal-backed patellar prostheses and anticipated that this was likely to be only the tip of an iceberg.

Patients and methods. From March 1987 to September 1990, a total of 151 AGC 2000 total knee replacements (Biomet Corp, UK) were inserted into 136 patients for osteoarthritis of the knee. Lateral release was never used: there were no severe valgus deformities. All components were fixed with bone cement. Suctions drains, continuous passive motion and prophylactic antibiotics were used in all cases.

Radiographs were taken within two days of operation and after three months, one year, and the onset of any complication. We have reviewed these for changes in the position of the prosthetic component and the hip-kneeankle (HKA) angle. The mean follow-up was 39 months (18 to 60$)$.

Results. The metal-backed patellar component failed in 14 of the 151 cases after an average time of 18 months. All 14 patients presented with pain and swelling, but radiography, including skyline views, showed abnormalities in only eight. The average HKA angle was $175^{\circ}$.

Discussion. Our results are very similar to other reported series (Table I). For all nine reports the average failure rate was $8.5 \%$ at an average time of 16 months. The results of the review suggest that most of the $8 \%$ to $11 \%$ failures occur within two years and that this rate does not increase with longer follow-up.

\section{N. Levi}

H. Kofoed

Department of Orthopaedics, Frederiksberg Hospital, University of Copenhagen, Denmark.

Correspondence to Dr N. Levi at Vermlandsgade 77, Copenhagen $2300 \mathrm{~S}$, Denmark.

C1994 British Editorial Society of Bone and Joint Surgery

0301-620X/94/4R97 \$2.00

J Bone Joint Surg [Br] 1994; 76-B:675.

Received 18 June 1993; Accepted 27 July 1993
Table I. Results in nine studies

\begin{tabular}{|c|c|c|c|c|}
\hline \multirow[b]{2}{*}{ Author } & \multirow{2}{*}{$\begin{array}{l}\text { Follow-up } \\
\text { (mth) }\end{array}$} & \multicolumn{2}{|c|}{ Failure rate } & \multirow{2}{*}{$\begin{array}{l}\text { Mean time } \\
\text { to failure } \\
\text { (mth) }\end{array}$} \\
\hline & & Number & Percent & \\
\hline Bayley et al (1988) & $?$ & $25 / ?$ & - & 18 \\
\hline Lombardi et al (1988) & 24 & $7 / 131$ & 5 & 16 \\
\hline Rosenberg et al (1988) & 24 & $12 / 122$ & 10 & 24 \\
\hline Stulberg et al (1988) & 19 & $16 / 150$ & 11 & 14 \\
\hline Sutherland (1988) & $?$ & $2 / ?$ & - & 14 \\
\hline $\begin{array}{l}\text { Felmet, de Nicola and } \\
\text { Springorum (1989) }\end{array}$ & $?$ & $3 / 51$ & 6 & 14 \\
\hline $\begin{array}{l}\text { Andersen, Ernst and } \\
\text { Frandsen (1991) }\end{array}$ & 14.5 & $8 / 111$ & 7 & 15 \\
\hline Baech and Kofoed (1991) & 13.5 & $5 / 47$ & 11 & 12.5 \\
\hline Levi and Kofoed (1994) & 39 & $14 / 151$ & 9.2 & 18 \\
\hline
\end{tabular}

No benefits in any form have been received or will be received from a commercial party related directly or indirectly to the subject of this article.

\section{REFERENCES}

Andersen HN, Ernst C, Frandsen PA. Polyethylene failure of metalbacked patellar components. Acta Orthop Scand 1991; 62:1-3.

Baech J, Kofoed H. Failure of metal-backed patellar arthroplasty. Acta Orthop Scand 1991; 62:166-8.

Bayley JC, Scott RD, Ewald FC, Holmes GB. Failure of the metal-backed patellar component after total knee replacement. J Bone Joint Surg [Am] 1988:70-A:668-74.

Felmet G, de Nicola U, Springorum HW. Failure of metal-backed uncemented patellar components. Acta Orthop Scand 1989; 60:715-7.

Lombardi AV, Engh GA, Volz RG, Albrigo JL, Brainard BJ. Fracture/ dissociation of the polyethylene in metal-backed patellar components in total knee arthroplasty. J Bone Joint Surg [Am] 1988; 70-A:675-9.

Rosenberg AG, Andriacchi TP, Barden R, Galante JO. Patellar component failure in cementless total knee arthroplasty. Clin Orthop 1988; 236:106-14.

Stulberg SD, Stulberg BN, Hamati Y, Tsao A. Failure mechanisms of metal-backed patellar components. Clin Orthop 1988; 236:88-105.

Sutherland CJ. Patellar component dissociation in total knee arthroplasty. Clin Orthop 1988; 228:178-81. 